Chirurgia (2019) 114: 243-250

No. 2, March - April

Copyright@ Celsius

http://dx.doi.org/10.21614/chirurgia.114.2.243

\title{
Hindgut and Midgut Neuroendocrine Tumors - Therapeutic Approach
}

\author{
Mihaela Madalina Gavrilescu ${ }^{1,2}$, Ionuț Huțanu ${ }^{1,2}$, Bogdan Filip ${ }^{1,2}$, Maria Gabriela Anitei ${ }^{1,2}$, Mihaela Buna-Arvinte ${ }^{1,2}$,

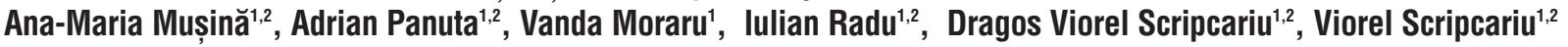 \\ ${ }^{1} 1^{\text {st }}$ Surgical Unit, Regional Institute of Oncology lași, Romania \\ 2Department of Surgery, "Grigore T Popa"University of Medicine and Pharmacy, Iași, Romania
}

Corresponding author:

Ionut Hutanu, MD

$1^{\text {st }}$ Surgical Unit, Regional Institute

of Oncology lași, Romania

E-mail: hionut65@yahoo.com
Received: 10.03 .2019 Accepted: 07.04.2019

\section{Rezumat}

Tumorile neuroendocrine ale intestinului primitiv mijlociu și posterior - atitudine terapeutică

Introducere: Tumorile neuroendocrine ale sistemului gastroenteropancreatic au comportamente variate, prezentări clinice şi indici de prognostic în funcție de localizarea lor anatomică. Prognosticul în cazul carcinoamelor neuroendocrine este nefavorabil din cauza gradului de diferențiere, metastazării precoce şi a gradului de invazivitate mare.

Material şi Metode: Pentru studiul prezent au fost evaluate foile de observație clinică şi urmăriți parametrii de interes.

Rezultate: În total, pe parcursul a 6 ani au fost diagnosticați şi tratați 37 de pacienți cu tumori neuroendocrine, indiferent de localizarea tumorii. Au fost înregistrati 9 pacienți cu tumori localizate la nivelul intestinului primitiv mijlociu si posterior, astfel: 5 pacienți cu tumori neuroendocrine colorectale şi 4 cazuri de tumori la nivelul intestinului subțire. Au fost efectuate 6 intervenții chirurgicale cu viză radicală, 2 pacienți au beneficiat de proceduri paliative şi un singur pacient la care s-a practicat doar o biopsie. Tumorile au fost evalute conform clasficarii WHO din 2010, care s-a bazat pe numărul de mitoze şi pe indicele de proliferare tumorală Ki67. Tratamentul adjuvant a fost adaptat în funcție de stadializare si de parametrii histopatologici.

Concluzii: În ciuda progreselor recente în ceea ce priveşte cunoaşterea TNE digestive, există încă multe aspecte controversate legate de managementul acestor pacienți, în principiu de secvențialitatea terapeutică. 
Cuvinte cheie: tumori neuroendocrine, tratament chirurgical, factori de prognostic

\section{Abstract}

Introduction: Neuroendocrine tumors of the gastro-entero-pancreatic system have a variety of components, clinical manifestations and prognostic indices according to their anatomical site. Therefore, their diagnostic and management strategies differ a great deal. Prognosis concerning NETs can be poor due to the degree of differentiation, early metastasizing and the high degree of invasiveness.

Material and Methods: For the present study, the patient files were evaluated and the parameters of interest were followed.

Results: Over the course of 6 years there were 37 patients diagnosed with and treated for NETs, regardless of primary tumor site. There were 9 patients with NETs of the primite mid- and hindgut thusly: 5 cases with colorectal NETs and 4 cases of small bowel NETs. 6 patients benefited from radical surgical treatment, 2 cases with palliative procedures and only one patient with tumor biopsy. The tumors were evaluated according to the 2010 WHO classification based on the number of mitoses and the Ki67 proliferation index. Adjuvant treatment was adapted according to staging and histopathological parameters.

Conclusions: Despite recent progress in managing NETs, there are still many controversial aspects regarding the management of these cases, mainly about timing the right sequence of therapy.

Key words: neuroendocrine tumors, surgical treatment, prognostic factors

\section{Introduction}

Gastro-intestinal neuroendocrine tumors (GINET) comprise a heterogeneous group of tumors, first described by Rudolf P.H. Heidenhain in 1870, originating in the neuroendocrine cells of the primitive intestine (1). The neuroendocrine system is a specialized network of cells, unequally distributed in the body in order to release hormones acting as neurotransmitters. The neuroendocrine system in the digestive tract plays a role in the control of local homeostasis, intestinal motility, secretion and digestion, and local metabolism. There are rare tumors, but lately the incidence has increased (2) probably due to improved diagnostic methods.

They stand out through a low growth rate, but a high dissemination potential. GI-NETs can be clinically symptomatic (or functional), or „silent” (non-functional). The necropsy studies showed a higher incidence than expected of neuroendocrine tumors, probably due to non-functional tumors (3).

After describing the first neuroendocrine tumors, their classification was attempted, but this was difficult due to their morphological and clinical heterogeneity. Based on their embryology, NETs were classified in 1963 as primitive tumors of the foregut (thymus, esophagus, stomach, lungs, duodenum, pancreas), of the midgut (appendix, ileum, caecum, ascendant colon) and hindgut (transverse and descendant colon, rectum) (3).

The first classification of NETs by the World Health Organization (WHO) was published in 1980, and would apply the term of "carcinoid" to most tumors. For the purposes of standardizing the terminology, it was updated between the years 2000 and 2004 based on the tumor pathology, thus eliminating the notion of "carcinoid tumor"; the patient prognosis depends on the functional behavior of the tumor and its differentiation. ENETS 
has also put forward the degrees of tumors based on their mitotic numbers and proliferative index (Ki67) (2): low grade $(\mathrm{g} 1)=$ $<2$ mitoses/10 high power fields (HPF) and a Ki67 index $\leq 2 \%$; middle grade $(\mathrm{G} 2)=2-20$ mitoses/10 HPF or Ki67 index between 3\% $20 \%$ and high grade (G3) $=>20$ mitoses $/ 10$ HPF or a Ki67 index $>20 \%$ (3).

The 2010 WHO classification defines the entire group of tumors as NENs and splits them into neuroendocrine tumors and carcinomas. Seeing as this classification is exclusively based on their histology, which cannot determine a complete patient prognosis for the patients, the American Joint Committee on Cancer and the European Society for Neuroendocrine Tumors have come up with a system of classification in stages and TNM grades. Besides the aforementioned types, there are two more categories: MANEC (mixed adeno-neuroendocrine carcinoma) and hyperplastic lesions (4).

The rectum is the second most frequent $(27,4 \%)$ site of formation for neuroendocrine gastrointestinal neoplasia (NEN), right behind its prevalence for the small intestine. Approximately $50 \%$ of the patients are symptomatic from the first presentation. Rectal pain, itchiness, hematochezia, weight-loss and obstipation are rather symptoms of a late first hospital presentation. Despite the ability of endocrine secretion for rectal NENs, the carcinoid syndrome is more of a rarity (5).

Several relevant factors for the prognosis of the disease have been identified: the size of the primary tumor, the presence of metastases, the presence of clinical symptoms, chromogranin A expression and radical surgical resection. In addition to that histological characteristics such as local invasion of the primary tumor, the degree of differentiation and the presence of lymphatic, vascular or neural invasion are also considered important prognostic factors for patients with NETs (6).

\section{Material and Methods}

The present study consists of a retrospective analysis of NET patients treated in the $I^{\text {st }}$
Surgical Oncology Clinic over a period of 6 years, whose definitive diagnosis was established by the Pathology Department of the Regional Oncology Institute in Iasi of which the clinic is part. The patient files were evaluated and the following parameters were taken into consideration: gender, age, primary tumor site, extension of the disease (localized vs. disseminated), metastatic sites (if any), hormonerelated symptoms, the date of the treatment, the therapeutic approach, the endoscopic or surgical anatomy of the tumor (Table 1).

The tumors were evaluated according to the 2010 WHO classification based on the number of mitoses and the Ki67 proliferation index. The number of mitoses was reported as G1 (<2/10 HPF), G2 (2-20/10 HPF) and G3 $(>20 / 10 \mathrm{HPF})$. The TNM staging was used both for the small bowel and the rectal NETs.

Written informed consent was obtained from all patients.

\section{Results}

Over the course of 6 years there were 37 patients diagnosed with and treated for NETs,

Table 1. Clinico-pathological features of NETs

\begin{tabular}{lc}
\hline Factors & No. \\
\hline Age & \\
$\leq 56$ & 8 \\
$>56$ & 1 \\
\hline Gender & \\
Masculine & 7 \\
Feminine & 2 \\
\hline Tumor site & \\
Rectum & 3 \\
Colon & 2 \\
Jejunum & 1 \\
Ileum & 3 \\
\hline Surgical intervention-extension & \\
Radical & 6 \\
Palliative & 2 \\
Biopsy & 1 \\
\hline Tumor stage of small bowel NETs & \\
II & 1 \\
III & 1 \\
IV & 2 \\
\hline Tumor stage of colorectal NETs & \\
II & 1 \\
III & 2 \\
IV & \\
\hline
\end{tabular}


regardless of primary tumor site. Most of them were pancreatic - 9 out of the 37 cases. Breast NETs also comprise a large portion of the study group. In addition, there was one case of a primary endometrial NET and one case of a NET of the uterine cervix.

There were 9 patients with NETs of the primitive mid- and hindgut thusly: 5 cases with colo-rectal NETs and 4 cases of small bowel NETs. The median age was 56 years, with a minimum of 38 and a maximum of 74 years (Table 2).

\section{Preoperative Diagnostic}

All patients with colorectal tumors have undergone colonoscopy and biopsy and staging through imaging before the surgical intervention. These investigations were performed as a result of the symptomatic presentation of the patients: rectorrhagia, bowel dysfunction, weight loss. Of all the patients included, 4 were initially diagnosed with adenocarcinoma. One patient was diagnosed through colonoscopy with synchronous ascending colon and midrectal tumors in whose case the pathology report found an undifferentiated carcinoma and a poorly differentiated neuroendocrine carcinoma respectively.

Patients with tumors located in the small bowel presented with various symptoms, ranging from abdominal discomfort and weight loss all the way to a carcinoid syndrome in one case. Imaging certified the presence of the tumor in the ileum in 3 cases and the jejunum in one case.

The presence of metastatic disease was confirmed in a patient with synchronous tumors (colon and rectum) and in two cases of small bowel tumors (Fig. 1, 2).

\section{Histopathological Results}

The surgical specimens were processed as per standard for hematoxylin eosin staining. According to their degree of differentiation, they were classified as well, moderately and poorly differentiated. In the colorectal group there were 3 mixed adeno-neuroendocrine
Table 2. Case distribution of NET site

\begin{tabular}{lr}
\hline NET site & No. of cases (\%) \\
\hline Pancreas & $9(24 \%)$ \\
\hline Breast & $8(22 \%)$ \\
\hline Colorectal & $5(13 \%)$ \\
\hline Small bowel & $4(11 \%)$ \\
\hline Gastric & $4(11 \%)$ \\
\hline Hepatic metastases of undefined primary site & $3(8 \%)$ \\
\hline Retroperitoneum & $2(5 \%)$ \\
\hline Cervical & $1(3 \%)$ \\
\hline Endometrium & $1(3 \%)$ \\
\hline
\end{tabular}



Figure 1. Tumor located at mid and superior rectum



Figure 2. Hepatic metastases

carcinomas, 1 poorly differentiated and 1 moderately differentiated neuroendocrine carcinomas (NEC). In patients with small 
Table 3. General characteristics of NETs

\begin{tabular}{lcc}
\hline & Colorectal (N) & Small bowel (N) \\
\hline NET G1 & - & 1 \\
\hline NET G2 & 1 & - \\
\hline CNE G3 & 1 & 3 \\
\hline MANEC & 3 & - \\
\hline IHC & 5 & 4 \\
\hline
\end{tabular}

bowel tumors the pathology report revealed one well differentiated and 3 poorly differentiated NECs (Table 3).

Immunohistochemistry was performed in all cases, testing for chromogranin, synaptophysine, CD56, Ki67 and the number of mitoses/10 HPF. The results regarding the colorectal cases showed the following: 1 case positive for chromogranin, 4 cases positive for synaptophysine, 4 positive for CD56; Ki67 varied between 50 and $90 \%$ in these cases. For the patients with small bowel tumors, chromogranin was positive in 2 cases, synaptophysine in 3, CD56 in all of them and the proliferation index varied between 2 and 50\% (Fig 3. A,B,C).

\section{Therapeutic approaches}

Of the 9 patients, 6 received radical surgical treatment. In the case of colorectal tumors, 1 patient with a cT3N2M0 imaging stage and a preoperative biopsy of rectal adenocarcinoma required neoadjuvant radio-chemotherapy, but with a minimal response by the postneoadjuvant restaging. The surgical approach consisted of the Hartmann procedure with complete mesorectal excision. In another case, the tumor localized in the mid-rectum, for which imaging results also described livermetastases, benefited from a very low anterior rectal resection with a colo-rectal anastomosis and protection ileostomy. A left high limited colon resection with manual colo-colic anastomosis was also performed for a tumor found in the splenic angle of the colon and another low anterior rectal resection for another patient. A single patient underwent a palliative surgical intervention due to the intraoperative discovery of two synchronous lesions on the ascending colon as well as the mid-rectum, and with
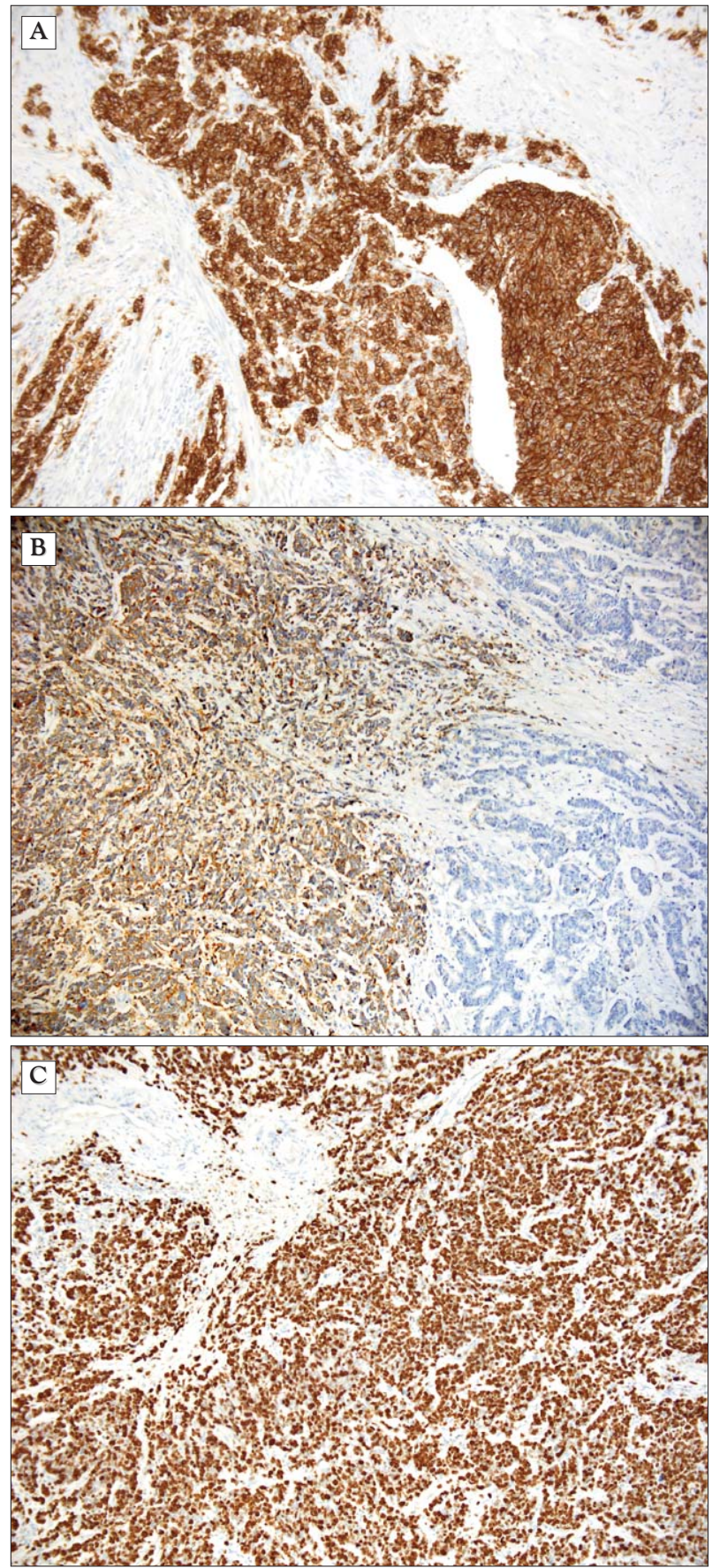

Figure 3. (A) CD56 positive in neuroendocrine cells (NEC) (IHC, anti CD56, 10x1). (B) Synaptofizine positive in NEC. (C) Expression of proliferation marker Ki67 in NEC

added peritoneal carcinomatosis lesions of the Douglas cul-de-sac and a liver metastasis in segment VIII. Concerning patients with small bowel tumors, just two have benefited from radical surgical treatment (enterectomies). In 
another patient, with the primary in the first jejunal loop, a gastro-enterostomy was performed, while one patient benefited only from tumor biopsy.

The management of adjuvant therapy was discussed for each patient in the multidisciplinary team meeting, with all the parameters of interest being assessed: imaging investigations, associated co-morbidities, intraoperative exploration, and histopathological results.

All our patients benefited from adjuvant chemotherapy, apart from two cases, one of small bowel and the other of rectal NETs, the latter also being associated with a bronhopulmonary cancer that was only confirmed after the initial intervention, as well as a multitude of associated diseases contraindicating any chemotherapy in his case.

Adjuvant chemotherapy was based on cisplatin and etoposide regimens in 5 cases as the first therapeutic line, and in one patient of them, diagnosed with a tumor in the first jejunal loop and liver metastases benefited from line II chemotherapy (oxaliplatin + capecitabine), an option that was implemented in the context of stationary disease. Two other patients followed CAPOX adjuvant therapy (capecitabine and oxaliplatin), both with the MANEC histopathological type.

\section{Discussions}

Neuroendocrine tumors of the gastro-enteropancreatic system have a variety of components, clinical manifestations and prognostic indices according to their anatomical site. Therefore, their diagnostic and management strategies differ a great deal.

To estimate the prognosis of patients, both TNM and WHO classification are used, the latter appears more specific and more sensitive (7).

Prognosis concerning NETs can be poor due to the degree of differentiation, early metastasizing and the high degree of invasiveness. The causes of these characteristics are associated with the following factors: neuroendocrine cells are derived from immature stem cells and the cancer cells themselves can secrete certain sub- stances promoting growth, proliferation and dissemination (8).

The similarity of the clinical behavior of these tumors localized in the digestive tract can mislead the diagnosis and therapeutic approach.

Neuroendocrine carcinomas of the rectum seem to have no apparent clinical specificity, more than one third of the patients being asymptomatic. Other patients have various degrees of bowel passage issues, such as abdominal discomfort, rectal pain, and rectorrhagia (9). In an article, Zhang et al. assessed the clinico-pathological and prognostic factors for patients with colorectal TNE. Out of the 49 patients included in the study, 17 of them were diagnosed by colonoscopy and biopsy. The most frequent tumors were located in the rectum. Just 27 patients underwent curative resections, the others benefiting just from palliative resections or just biopsies. All their patients received adjuvant chemotherapy based on cisplatinum and etoposide. The 5 years survival rate was around 6,9\% (8).

Another study on 270 patients with primitive mid- and hindgut NETs performed by Jan and col. show the most frequent primary site to be the small bowel followed by rectal tumors. The presence or absence of a carcinoid syndrome had no apparent impact on their long-term survival, even though the majority of those presenting with carcinoid syndrome had a more advanced disease stage. This seemed to suggest that the carcinoid syndrome is not an independent prognostic factor, but rather an epiphenomenon of the tumor load with a therapeutic and clinical impact (6).

The best treatment for rectal NETs remains uncertain. So far, surgical resection remains the most efficient option. The prognosis is better for patients without metastases (9).

In a prospective, randomized, placebo-controlled study in which long-acting repeatable octreotide (LAR) was administered in $30 \mathrm{mg}$ doses every 4 weeks in small bowel NETs (the PROMID study), the antiproliferative efficiency of LAR octreotide was confirmed. The median time to tumor progression was 14,3 months in the case of LAR octreotide, vs just 6 months 
for the placebo group. Based on these results, the administration of somatostatin analogues, especially LAR octreotide, is now recommended for its antiproliferative efficiency in functional and non-functional small bowel tumors (10).

Even more recently, the CLARINET study showed that in 101 patients with digestive NETs who received $120 \mathrm{mg}$ of lanreotide, progression-free survival was not reached, as opposed to 18 months in the case of the 103 patients in the placebo-control group. Both these studies underline the increase in the antiproliferative effects of the two substances for low-Ki67 patients (G1 or G2 NETs with a Ki67 $<10 \%$ ) with a stable disease and a high expression of somatostatin receptors, who were evaluated through imaging (11).

Everolimus has already been approved for use in treating pancreatic NETs, based on the results of the RADIANT3 study. The most recent clinical study evaluating everolimus for the treatment of NETs, RADIANT4, has shown that the drug works both on pulmonary tumors as well as on those originating in the gastro-intestinal tract. The results of the study indicate that the median time to disease progression was on average 11 months with everolimus versus 3,9 months in the placebo group (12).

Promising data on target peptide receptor radiotherapy (PRRT) in the treatment of TNE with hepatic metastases by using DOTATOC or DOTATATE labeled ${ }^{90}$ Yttrium and ${ }^{17}$ Lutetium were obtained. These compounds have the ability to irradiate the tumor and metastases by a specific pathway to a receptor subtype. Targeted radiotherapy can provide appropriate radiation doses to reduce tumor volume. This therapy can be considered in functional and non-functional TNEs functional and non-functional NETs with positive results for somatostatin receptor scintigraphy, irrespective of primary tumor location (13).

Peptide receptor radionuclide therapy (PRRT) was debated in literature, however, prospective studies were rare. Positive results were published in the NETTER-1 clinical trial performed on a group of 229 patients with neuroendocrine tumors of the midgut, advanced, inoperable or progression-prolonged treatment with octreotide. Patients were divided into 2 groups and treated with ${ }^{17}$ LutetiumDOTATATE (Lutathera) and $30 \mathrm{mg}$ Sandostatin LAR every 8 weeks, respectively with Sandostatin LAR $60 \mathrm{mg}$ every 4 weeks. The estimated rate of progression-free survival at month 20 was $65.2 \%$ in the ${ }^{177} \mathrm{Lu}$-Dotatate group and $10.8 \%$ in the control group (14).

Our study group included a small number of NETs located in the digestive tract and a smaller number with colorectal localization. Colorectal resections performed for NETs in our clinic represented less than $0.1 \%$ of the total number of surgical procedures performed for colorectal tumors. It is difficult to explain the lower percentage as compared to the expected $1-2 \%$, according to the literature (15). It is possible that some patients with nondifferentiated neuroendocrine tumors with metastatic disease and the standard histological examination on the biopsy have suggested an adenocarcinoma and the therapeutic decision in these cases was a non-resectional one.

Given that the increase in these tumors in both the symptomatic individuals and the implementation of the colorectal cancer screening protocols has been argued over the last few years, it is evident that the neuroendocrine tumors are omitted from the orphan tumor spectrum and that the medical community has a better understanding of diagnosis and therapy options. The discovery of new biomarkers to complete the limitations of chromogranin A, new immunohistological markers for the assessment of differentiation, tumor proliferation, primitive origin, evaluation of prognosis and therapeutic possibilities as well as the improvement of radiological techniques for the detection of metastatic disease are necessary for the diagnosis, therapeutic approach and follow-up in this pathology.

\section{Conflict of Interest}

The authors declare no conflicts of interests. 


\section{Acknowledgment}

We want to express our gratitude to Dr. Catalina Acatrinei-Insuratelu, form the Department of Pathology, in the Regional Institute of Oncology Iaşi, who was kind enough to provide the immunohistochemistry images that appear in this article.

\section{References}

1. de Herder WW, Rehfeld JF, Kidd M, Modlin IM. A short history of neuroendocrine tumours and their peptide hormones. Best Pract Res Clin Endocrinol Metab. 2016;30(1):3-17.

2. Yao JC, Hassan M, Phan A, Dagohoy C, Leary C, Mares JE, et al. One hundred years after 'carcinoid': epidemiology of and prognostic factors for neuroendocrine tumors in 35825 cases in the United States. J Clin Oncol. 2008 Jun 20;26(18):3063-72.

3. Öberg KE. Gastrointestinal neuroendocrine tumors. Ann Oncol. 2010 0ct;21 Suppl 7:vii72-80.

4. Chablaney S, Zator ZA, Kumta NA. Diagnosis and Management of Rectal Neuroendocrine Tumors. Clin Endosc. 2017:50(6):530-36.

5. Gut P, Waligórska-Stachura J, Czarnywojtek A, Sawicka-Gutaj N, Baczyk M, Ziemnicka K, et al. Hindgut neuroendocrine neoplasms characteristics and prognosis. Arch Med Sci. 2017;13(6):1427-32.

6. Jann H, Roll S, Couvelard A, Hentic O, Pavel M, Müller-Nordhorn J, et al. Neuroendocrine tumors of midgut and hindgut origin: tumornode-metastasis classification determines clinical outcome. Cancer. 2011;117(15):3332-41.
7. Shen $\mathrm{C}$, Yin $\mathrm{Y}$, Chen H, Tang S, Yin X, Zhou Z,et al. Neuroendocrine tumors of colon and rectum: validation of clinical and prognostic values of the World Health Organization 2010 grading classifications and European Neuroendocrine Tumor Society staging systems. Oncotarget. 2017;8(13):22123-34.

8. Zhang Y, Xie J, Wang J, Yang D, Jiang Z, Han G, et al. Clinicopathological and prognostic analysis of neuroendocrine carcinoma of the colorectum. Adv Clin Exp Med. 2016;25(4):719-24.

9. Yangong H, Shi C, Shahbaz M, Zhengchuan N, Wang J, Liang B, et al. Diagnosis and treatment experience of rectal carcinoid (a report of 312 cases). Int J Surg. 2014;12(5):408-11.

10. Rinke A, Müller HH, Schade-Brittinger C, Klose KJ, Barth P, Wied M, et al. Placebo-controlled, double-blind, prospective, randomized study on the effect of octreotide LAR in the control of tumor growth in patients with metastatic neuroendocrine midgut tumors: a report from the PROMID Study Group. J Clin Oncol. 2009;27(28):4656-63.

11. Caplin ME, Pavel M, Cwikła JB, Phan AT, Raderer M, Sedláčková E, et al. Lanreotide in metastatic enteropancreatic neuroendocrine tumors. N Engl J Med. 2014;371(3):224-33.

12. Yao JC, Shah MH, Ito T, Bohas CL, Wolin EM, Van Cutsem E,et al. Everolimus for advanced pancreatic neuroendocrine tumors. N Engl J Med. 2011;364(6):514-23.

13. Bodei L1, Cremonesi M, Ferrari M, Pacifici M, Grana CM, Bartolomei $\mathrm{M}$, et al. Long-term evaluation of renal toxicity after peptide receptor radionuclide therapy with 9OY-DOTATOC and 177Lu-DOTATATE: the role of associated risk factors. Eur J Nucl Med Mol Imaging. 2008;35(10):1847-56.

14. Strosberg J, El-Haddad G, Wolin E, Hendifar A, Yao J, Chasen B, et al. Phase 3 Trial of $177 \mathrm{Lu}$-Dotatate for Midgut Neuroendocrine Tumors. N Engl J Med. 2017;376(2):125-35.

15. Kang H, O'Connell JB, Leonardi MJ, Maggard MA, McGory ML, Ko CY. Rare tumors of the colon and rectum: a national review. Int $\mathrm{J}$ Colorectal Dis. 2007; 22(2):183-9. Epub 2006 Jul 15. 